\title{
Authentic Assessment Analysis Based on The Curriculum 2013 at SMP Negeri 7 Muaro Jambi
}

\section{Analisis Penilaian Autentik Berdasarkan Kurikulum 2013 di SMP Negeri 7 Muaro Jambi}

\author{
Mia Rima Agustina ${ }^{1)}$, Suraida $^{2)}$, Alfian $^{3)}$, Boby Syefrinando $^{4)}$ \\ Email:miajambi011@gmail.com \\ ${ }^{1)}$ Mahasiswa Program Studi Tadris Biologi UIN Sulthan Thaha Saifuddin Jambi \\ ${ }^{4,32)}$ Dosen Program Studi Tadris Biologi UIN Sulthan Thaha Saifuddin Jambi
}

\begin{abstract}
The 2013 curriculum requires the use of authentic assessment, where students are assessed for their readiness, process, and learning outcomes as a whole. This research was conducted at Muaro Jambi 7 Junior High School which aimed to find out the implementation of authentic assessment subjects at Muaro Jambi Junior High School and to find out whether authentic assessment was carried out properly or not. Data collection methods used in the study are documentation studies, interviews and questionnaires. Subjects used in this study were biology teachers who used the 2013 curriculum and VIII grade students at Junior High School of Muaro Jambi 7th. The results obtained showed that all biology teachers had carried out authentic assessments. The teacher has carried out an authentic assessment during the learning process which includes three aspects of assessment namely attitudes, knowledge, and skills. However, in the process of authentic assessment there are still some obstacles, namely the number of assessment formats that must be made by the teacher with limited availability of time so that the teacher is not optimal in carrying out authentic assessments. The many aspects that must be assessed in the 2013 Curriculum assessment, so that the teacher takes a long time to make an assessment.
\end{abstract}

Keywords : analysis, authentic assessment, 2013 curriculum.

\begin{abstract}
Abstrak: Kurikulum 2013 mensyaratkan penggunaan penilaian autentik, dimana siswa dinilai kesiapannya, proses, dan hasil belajar secara utuh. Penelitian ini dilakukan di Sekolah Menengah Pertama Negeri 7 Muaro Jambi yang bertujuan untuk mengetahui pelaksanaan penilaian autentik di Sekolah Menengah Pertama Negeri Muaro Jambi dan untuk mengetahui apakah penilaian autentik dilaksanakan dengan baik atau tidak. Metode pengumpulan data yang digunakan dalam penelitian adalah studi dokumentasi, wawancara dan angket. Subjek yang digunakan dalam penelitian ini yaitu guru mata pelajaran biologi yang menggunakan kurikulum 2013 dan siswa kelas VIII di Sekolah Menengah Pertama Negeri 7 Muaro Jambi. Hasil penelitian yang diperoleh menunjukkan bahwa seluruh guru biologi sudah melaksanakan penilaian autentik. Guru sudah melaksanakan penilaian autentik pada saat proses pembelajaran yang meliputi tiga aspek penilaian yaitu sikap, pengetahuan, dan keterampilan. Namun, pada proses pelaksanaan penilaian autentik masih ada beberapa kendala yaitu banyaknya format penilaian yang harus dibuat oleh guru dengan ketersediaan waktu yang guru miliki terbatas sehingga membuat guru kurang maksimal dalam melaksanakan penilaian autentik. Banyaknya aspek yang harus dinilai dalam penilaian Kurikulum 2013, sehingga guru membutuhkan waktu yang lama untuk melakukan penilaian.
\end{abstract}

Kata kunci: analisis, penilaian autentik, kurikulum 2013. 


\section{PENDAHULUAN}

Penilaian dalam pendidikan merupakan suatu proses pengumpulan data atau informasi hasil belajar siswa, kemudian data yang telah diperoleh akan diolah untuk mengetahui atau mengukur pencapaian hasil belajar siswa. Pengumpulan informasi ini dapat melalui penilaian autentik, ulangan harian, ulangan tengah semester, ulangan akhir semester dan sebagainya (Cahyadi F \& Purwandari A.,2014). Kurikulum 2013 mensyaratkan penggunaan penilaian autentik (authentic assesment), dimana siswa dinilai kesiapannya, proses, dan hasil belajar secara utuh. Keterpaduan penilaian ketiga komponen tersebut akan menggambarkan kapasitas dan perolehan belajar siswa. Penilaian autentik seperti portofolio dan jurnal belajar juga dapat meningkatkan kemampuan metakognisi dan Motivasi peserta didik (Sadikin, A., Aina. M \& Hakim. N. 2016; Sadikin, A. 2018). Penilaian kurikulum sebelumnya hanya bertolak pada hasil akhir belajar. Hasil akhir belajar dideskripsikan sebagai perolehan hasil belajar siswa selama mengikuti pembelajaran tanpa memberikan penilaian proses belajar. Kurikulum 2013 yang mensyaratkan penggunaan penilaian autentik memberikan paradigma baru dalam proses penilaian hasil belajar siswa. Kurikulum sebelumnya lebih mementingkan domain kognitif namun Kurikulum 2013 ini cenderung menyeimbangkannya dengan penekanan lebih pada domain psikomotor dan afektif (Pantiwati, 2013). Penilaian dalam kurikulum 2013 mengharuskan ada keseimbangan antara penilaian afektif, kognitif dan psikomotorik.

Penilaian autentik lebih mengukur keseluruhan hasil belajar peserta didik karena penilaian ini menilai kemajuan belajar peserta didik bukan hanya hasil akhir belajar peseta didik. Dengan adanya penilaian proses maka siswa menjadi senang untuk melaksanakan tahapan demi tahapan proses pembelajaran yang pada gilirannya akan meningkatkan emosi positif siswa (Sadikin. A, 2015). Adanya penilaian autentik diharapkan guru dapat melakukan berbagai macam teknik penilaian untuk mengukur aspek sikap, pengetahuan dan keterampilan. Kunandar (2014) juga menjelaskan, hasil penilaian autentik dapat digunakan oleh guru untuk merencanakan program perbaikan (remedial), pengayaan (enrichment) maupun pelayanan konseling. Selain itu hasil penilaian autentik juga dapat digunakan sebagai bahan untuk memperbaiki proses pembelajaran (assessment for learning). Sistem penilaian yang digunakan oleh guru, sekolah bahkan pemerintah saat ini masih menggunakan penilaian yang hanya menekankan pada kompetensi pengetahuan, bahkan hanya aspek pengetahuan tingkat rendah. Penilaian masih dilakukan dengan memberikan sejumlah soal yang memiliki jawaban pendek, isian atau pertanyaan pilihan ganda dan menilai sejumlah tugas terbatas yang mungkin tidak sesuai dengan apa yang dikerjakan selama proses pembelajaran berlangsung. Dalam penilaian ini jarang menilai aspek sikap dan aspek keterampilan siswa (Muchtar, 2010).

Penilaian autentik dapat dijadikan alternatif solusi dalam menilai perkembangan belajar siswa secara lebih komprehensif dan objektif mengingat penilaian autentik lebih menekankan pada pengembangan alat penilaian yang lebih akurat untuk mencerminkan dan mengukur apa yang dinilai dalam pendidikan (Mutalazimah, 2008, hal. 35). Mengingat persepsi siswa juga penting diperhatikan dalam proses pembelajaran, ketika persepsi positif maka pembelajaran pun akann berjalan positif dan sebaliknya (Sadikin. A, 2015). Menurut Permendikbud Nomor 104 tahun 2014 bahwa penilaian autentik adalah bentuk penilaian yang menghendaki peserta didik menampilkan sikap, menggunakan pengetahuan dan keterampilan yang diperoleh dari pembelajaran dalam melakukan tugas pada situasi yang sesungguhnya. Pada pasal 2 ayat 3 permen tersebut dijabarkan bahwa dalam melakukan penilaian terhadap hasil belajar peserta didik pendekatan utama yang dilakukan adalah penilaian autentik dengan bentuk-bentuk yang dapat dilakukan mencakup 
penilaian berdasarkan pengamatan, tugas ke lapangan, portofolio, proyek, produk, jurnal, kerja laboratorium dan unjuk kerja, serta penilaian diri.

Berdasarkan uraian yang disajikan di atas, penting dilakukan penelitian untuk mengetahui pelaksanaan penilaian autentik mata pelajaran biologi domain afektif, kognitif dan psikomotorik berdasarkan Kurikulum 2013. SMP Negeri 7 Muaro Jambi merupakan salah satu sekolah pelaksana Kurikulum 2013. Penelitian ini dilakukan di SMP Negeri 7 Muaro Jambi. berkaitan dengan ditemuinya hambatan pelaksanaan penilaian autentik yang dilakukan oleh guru. Pelaksanaan proses penilaian autentik yang kompleks menyita waktu sehingga guru belum bisa memenuhi tuntutan penilaian Kurikulum 2013 secara utuh. Sebagaimana wawancara pada tanggal 21 April 2018 guru yang mengatakan bahwa dalam menerapkan penilaian autentik, guru masih merasa kesulitan dalam membagi waktu karena guru terlalu fokus saat mengajar sehingga guru kekurangan waktu dalam menentukan nilai. Guru juga merasa sulit dalam menyusun nilai dan menentukan yang didapatkan para siswa dari berbagai aspek penilaian autentik baik sikap, pengetahuan, maupun keterampilan ke dalam daftar nilai. Penelitian ini bertujuan untuk mengetahui pelaksanaan penilaian autentik berdasarkan kurikulum 2013 pada mata pelajaran IPA Terpadu di SMP Negeri 7 Muaro Jambi. Penelitian ini akan menyajikan analisis pelaksanaan penilaian autentik yang dilaksanakan di sekolah tersebut.

\section{METODE PENELITIAN}

Penelitian ini merupakan penelitian Mixed Methods. Penelitian mixed methods atau metode kombinasi yaitu metode yang menggabungkan antara metode kualitatif dan metode kuantitatif dengan cara mecampur kedua metode tersebut secara seimbang (Sugiyono, 2013). Jenis data pada penelitian ini yaitu data kualitatif dan kuantitatif. Data kualitatif diperoleh dari observasi, wawancara, dan dokumentasi, sedangkan data kuantitatif didapatkan dari angket siswa dan angket guru. Kedua data tersebut di elaborasikan sehingga mendapatkan kesimpulan yang lengkap dengan data kuantitatif didukung dengan data kualitatif (Budiarti. R.S \& Sadikin, A. 2015).

Sumber data penelitian ini adalah siswa kelas VIII dan guru IPA Terpadu Sekolah Menengah Pertama Negeri 7 Muaro Jambi. Data dari siswa diperoleh melalui angket dan wawancara, sedangkan data dari guru diperoleh melalui angket dan wawancara tentang penilaian autentik. Data-data juga dilengkapi dengan hasil observasi dan dokumentasi mengenai penilaian autentik berdasarkan kurikulum 2013. Teknik pengumpulan data dilakukan dengan teknik triangulasi data (gabungan) yaitu teknik wawancara, observasi dan angket. Analisis data dan pengujian kredibilitas data dapat dilakukan bersamaan dengan proses pengumpulan data dan setelah selesai pengumpulan data (Sugiyono, 2013). Data wawancara (interview) di transkip, coding dan direduksi untuk menarik sebuah kesimpulan. 


\section{HASIL DAN PEMBAHASAN}

\section{Data Hasil Kuesioner}

a. Tanggapan siswa terhadap perencanaan penilaian autentik

Tabel 1. Kategori kecenderungan tingkat analisis penilaian autentik berdasarkan aspek perencanaan.

\begin{tabular}{|c|c|c|c|}
\hline No & Kategori & Jumlah & Persentase \% \\
\hline 1 & Selalu & 0 & 0 \\
\hline 2 & Sering & 39 & $100 \%$ \\
\hline 3 & Jarang & 0 & 0 \\
\hline 4 & Kadang-kadang & 0 & 0 \\
\hline 5 & Tidak Pernah & 0 & 0 \\
\hline
\end{tabular}

Berdasarkan hasil analisis data di atas menunjukkan bahwa penilaian autentik berdasarkan aspek perencanaan pada tabel 1 dapat diketahui persentase responden paling banyak berjumlah 39 responden dikategorikan sering dengan persentase (100\%).

\section{b. Tanggapan siswa terhadap pelaksanaan penilaian autentik}

Tabel 2. Kategori kecenderungan tingkat analisis penilaian autentik berdasarkan aspek pelaksanaan.

\begin{tabular}{|c|c|c|c|}
\hline No & Kategori & jumlah & Persentase \% \\
\hline 1 & Selalu & 0 & 0 \\
\hline 2 & Sering & 0 & 0 \\
\hline 3 & Jarang & 39 & $100 \%$ \\
\hline 4 & Kadang-kadang & 0 & 0 \\
\hline 5 & Tidak Pernah & 0 & 0 \\
\hline
\end{tabular}

Berdasarkan hasil analisis data di atas menunjukkan bahwa penilaian autentik berdasarkan aspek pelaksanaan pada tabel 2 dapat diketahui persentase responden paling banyak berjumlah 39 responden dikategorikan jarang dengan persentase (100\%).

\section{c. Tanggapan siswa terhadap teknik dan instrumen penilaian sikap (Afektif)}

Tabel 3. Kategori kecenderungan tingkat analisis penilaian autentik berdasarkan aspek penilaian afektif

\begin{tabular}{|c|c|c|c|}
\hline No & Kategori & Jumlah & Persentase \% \\
\hline 1 & Selalu & 0 & 0 \\
\hline 2 & Sering & 0 & 0 \\
\hline 3 & Jarang & 0 & 0 \\
\hline 4 & Kadang-kadang & 28 & $72 \%$ \\
\hline 5 & Tidak Pernah & 11 & $28 \%$ \\
\hline
\end{tabular}

Berdasarkan hasil analisis data di atas menunjukkan bahwa penilaian autentik berdasarkan aspek penilaian sikap (Afektif) pada tabel 3 dapat diketahui persentase responden paling banyak berjumlah 28 responden dikategorikan kadang-kadang dengan persentase (72\%). Kemudian persentase responden paling dikit berjumlah 11 responden dikategorikan tidak pernah dengan persentase (28\%). 


\section{d. Tanggapan siswa terhadap teknik dan instrumen penilaian pengetahuan (kognitif)}

Tabel 4. Kategori kecenderungan tingkat analisis penilaian autentik berdasarkan aspek penilaian pengetahuan (kognitif)

\begin{tabular}{|c|c|c|c|}
\hline No & Kategori & Jumlah & Persentase \% \\
\hline 1 & Selalu & 0 & 0 \\
\hline 2 & Sering & 0 & 0 \\
\hline 3 & Jarang & 0 & 0 \\
\hline 4 & Kadang-kadang & 39 & $100 \%$ \\
\hline 5 & Tidak Pernah & 0 & 0 \\
\hline
\end{tabular}

Berdasarkan hasil analisis data diatas menunjukkan bahwa penilaian autentik berdasarkan aspek penilaian kognitif (Pengetahuan) pada tabel 10 dapat diketahui persentase responden paling banyak berjumlah 39 responden dikategorikan kadang-kadang dengan persentase $(100 \%)$.

\section{e. Tanggapan siswa terhadap teknik dan instrumen penilaian keterampilan (psikomotorik)}

Tabel 5. Kategori kecenderungan tingkat analisis penilaian autentik berdasarkan aspek penilaian keterampilan (psikomotorik).

\begin{tabular}{|l|l|c|c|}
\hline No & Kategori & Jumlah & Persentase \% \\
\hline 1 & Selalu & 38 & $97 \%$ \\
\hline 2 & Sering & 1 & $3 \%$ \\
\hline 3 & Jarang & 0 & 0 \\
\hline 4 & Kadang-kadang & 0 & 0 \\
\hline 5 & Tidak Pernah & 0 & 0 \\
\hline
\end{tabular}

Berdasarkan hasil analisis data diatas menunjukkan bahwa penilaian autentik berdasarkan aspek penilaian keterampilan (psikomotor) pada tabel 5 dapat diketahui persentase responden paling banyak berjumlah 38 responden dikategorikan selalu dengan persentase (97\%). Kemudian persentase responden paling sedikit berjumlah 1 responden dikategorikan sering dengan persentase (3\%). Berikut ini adalah deskripsi persepsi guru biologi terhadap analisis penilaian autentik pada pembelajaran biologi di Sekolah Menengah Pertama Negeri 7 Muaro Jambi dapat dilihat pada tabel 6 sebagai berikut:

\section{f. Tanggapan Guru Terhadap Perencanaan Penilaian Autentik}

Tabel 6. Tanggapan guru terhadap perencanaaan penilaian autentik

\begin{tabular}{|l|l|c|c|}
\hline No & Kategori & Jumlah & Persentase \% \\
\hline 1 & Selalu & 2 & 66,66 \\
\hline 2 & Sering & 1 & 33,33 \\
\hline 3 & Jarang & 0 & 0 \\
\hline 4 & Kadang-kadang & 0 & 0 \\
\hline 5 & Tidak Pernah & 0 & 0 \\
\hline
\end{tabular}

Berdasarkan hasil analisis data di atas menunjukkan bahwa penilaian autentik berdasarkan aspek perencanaan pada tabel 6 dapat diketahui persentase responden paling banyak berjumlah 3 responden dikategorikan selalu dengan persentase $(66,66 \%)$. Kemudian 
persentase responden paling sedikit berjumlah 1 dikategorikan sering dengan persentase $(33,33 \%)$.

\section{g. Tanggapan Guru Terhadap Pelaksanaan Penilaian Autentik}

Tabel 7. Tanggapan guru terhadap pelaksanaan penilaian autentik

\begin{tabular}{|l|l|c|c|}
\hline No & Kategori & Jumlah & Persentase \% \\
\hline 1 & Selalu & 1 & 33,33 \\
\hline 2 & Sering & 2 & 66,66 \\
\hline 3 & Jarang & 0 & 0 \\
\hline 4 & Kadang-kadang & 0 & 0 \\
\hline 5 & Tidak Pernah & 0 & 0 \\
\hline
\end{tabular}

Berdasarkan hasil analisis data di atas menunjukkan bahwa penilaian autentik berdasarkan aspek pelaksanaan pada tabel 7 dapat diketahui persentase responden paling banyak berjumlah 2 responden dikategorikan sering dengan persentase (66,66\%). Kemudian persentase responden paling sedikit berjumlah 1 dikategorikan selalu dengan persentase $(33,33 \%)$.

\section{h. Tanggapan Guru Terhadap Analisis dan Pelaporan (Hasil) Penilaian Autentik}

Tabel 8. Tanggapan guru terhadap pelaporan (Hasil) penilaian autentik

\begin{tabular}{|l|l|c|c|}
\hline No & Kategori & Jumlah & Persentase \% \\
\hline 1 & Selalu & 0 & 0 \\
\hline 2 & Sering & 0 & 0 \\
\hline 3 & Jarang & 2 & 66,67 \\
\hline 4 & Kadang-kadang & 1 & 33,33 \\
\hline 5 & Tidak Pernah & 0 & 0 \\
\hline
\end{tabular}

Berdasarkan hasil analisis data di atas menunjukkan bahwa penilaian autentik berdasarkan aspek pelaporan (hasil) penilaian autentik pada tabel 8 dapat diketahui persentase responden paling banyak berjumlah 2 responden dikategorikan jarang dengan persentase $(66,67 \%)$. Kemudian persentase responden paling sedikit berjumlah 1 dikategorikan kadangkadang dengan persentase $(33,33 \%)$.

\section{i. Tanggapan Guru Terhadap Penilaian Sikap (Afektif)}

Tabel 9. Tanggapan guru terhadap penilaian sikap

\begin{tabular}{|l|l|c|c|}
\hline No & Kategori & Jumlah & Persentase \% \\
\hline 1 & Selalu & 0 & 0 \\
\hline 2 & Sering & 0 & 0 \\
\hline 3 & Jarang & 2 & 66,67 \\
\hline 4 & Kadang-kadang & 1 & 33,33 \\
\hline 5 & Tidak Pernah & 0 & 0 \\
\hline
\end{tabular}

Berdasarkan hasil analisis data di atas menunjukkan bahwa penilaian autentik berdasarkan aspek penilaian sikap pada tabel 9 dapat diketahui persentase responden paling banyak berjumlah 2 responden dikategorikan jarang dengan persentase $(66,67 \%)$. Kemudian persentase responden paling sedikit berjumlah 1 responden dikategorikan kadang-kadang dengan persentase $(33,33 \%)$. 


\section{j. Tanggapan Guru Terhadap Penilaian Pengetahuan (Kognitif)}

Tabel 10. Tanggapan guru terhadap penilaian pengetahuan (kognitif).

\begin{tabular}{|l|l|c|c|}
\hline No & Kategori & jumlah & Persentase \% \\
\hline 1 & Selalu & 0 & 0 \\
\hline 2 & Sering & 0 & 0 \\
\hline 3 & Jarang & 1 & 33,33 \\
\hline 4 & Kadang-kadang & 2 & 66,67 \\
\hline 5 & Tidak Pernah & 0 & 0 \\
\hline
\end{tabular}

Berdasarkan hasil analisis data di atas menunjukkan bahwa penilaian autentik berdasarkan aspek penilaian pengetahuan pada tabel 10 dapat diketahui persentase responden paling banyak berjumlah 2 responden dikategorikan kadang-kadang dengan persentase $(66,67 \%)$. Kemudian persentase responden berjumlah 1 dikategorikan jarang dengan persentase $(33,33 \%)$.

\section{k. Tanggapan Guru Terhadap Penilaian Keterampilan (Psikomotor)}

Tabel 11. Tanggapan guru terhadap penilaian keterampilan (psikomotor).

\begin{tabular}{|l|l|c|c|}
\hline No & Kategori & jumlah & Persentase \% \\
\hline 1 & Selalu & 3 & 100 \\
\hline 2 & Sering & 0 & 0 \\
\hline 3 & Jarang & 0 & 0 \\
\hline 4 & Kadang-kadang & 0 & 0 \\
\hline 5 & Tidak Pernah & 0 & 0 \\
\hline
\end{tabular}

Berdasarkan hasil analisis data di atas menunjukkan bahwa penilaian autentik berdasarkan aspek penilaian keterampilan pada tabel 11 dapat diketahui persentase responden paling banyak berjumlah 3 responden dikategorikan selalu dengan persentase (100\%).

\section{Data hasil wawancara}

Berdasarkan hasil wawancara yang peneliti lakukan dengan Ibu Yetti Syafridar, S. Pd guru bidang studi IPA Terpadu materi Biologi yang menggunakan kurikulum 2013 di Sekolah Menengah Pertama Negeri 7 Muaro Jambi pada tanggal 21 Mei 2018 mengatakan bahwa "Persiapan yang dilakukan dari sekolah ada pelatihan dan pelatihan ini biasanya diadakan satu kali dalam satu semester". Pendapat lain juga disampaikan pada guru bidang biologi yang menggunakan kurikulum 2013 yaitu Ibu Hj. Yenni P, M. Pd. Menurut Ibu Hj. Yenni P, M. Pd guru bidang studi IPA Terpadu materi Biologi yang menggunakan kurikulum 2013 di Sekolah Menengah Pertama Negeri 7 Muaro Jambi pada tanggal 21 Mei 2018 mengatakan bahwa "Kita buat Rencana Pelaksanaan Penilaian (RPP), di Rencana Pelaksanaan Pembelajaran (RPP) itu udah di siapkan berbagai macam penilaiannya yang akan dilaksanakan, kalau penilaian tentang keterampilan harus buat rubriknya untuk penilaian. Penilaian sikap dikelaskan ada banyak macamnya, ada tentang jurnal, penilaian diri, penilaian sejawat, semuanya di siapkan dulu item mana yang akan dinilai”.

Berdasarkan pernyataan Ibu Yetti dan Ibu Yenni persiapan yang pertama yaitu dari sekolah yaitu pelatihan yang dilakukan sebelum pembelajaran atau pelatihan yang dilakukan hanya sekali dalam satu semester.Pelatihan ini biasanya dilakukan untuk membantu guru dalam melaksanakan kurikulum 2013. Dan yang dilakukan selanjutnya oleh guru adalah dengan 
membuat Rencana Pelaksanaan Pembelajaran (RPP) yang didalamnya sudah termuat rubrik dan instrument penilaian. Instrumen Penilaian sesungguhnya berguna untuk lebih menjelaskan proses penilaian yang digunakan masing-masing teknik penilaian.

Berdasarkan salah satu uraian guru biologi yaitu ibu Yetti proses penialaian autentik "Prosesnya jika penilaian afektif dan kognitif, saya melihat dari mereka berdiskusi, dari mereka berkelompok, saya minta mereka praktek. Saya minta mereka melihat LKS dan mengikuti langkah-langkahnya, tapi masih ada juga yang belum berani, di situlah saya menilai, mana yang aktif, mana yang tanggap ada yang masih menunggu, jadi proses penilaiannya itu saya lihat dengan keaktifan mereka,kalau penilaian psikomotor itu di saat praktek karena ada dalam buku penilaiannya seperti nilai proyek dan lainnya". Dari hasil wawancara di atas dapat disimpulkan bahwa pelaksanaan dan proses penilaian autentik mereka lakukan dengan kesesuaian Rencana Pelaksanaan Pembelajaran (RPP) dan juga selalu melibatkan siswa dalam pembelajaran dan penilaian. Dalam melakukan penilaian autentik guru mengatakan bahwa banyak anak yang kurang memahami materi yang disampaikan dan kebanyakan dari para guru kekurangan waktu karena terlalu banyak penilaian dan dikarenakan guru terlalu fokus pada mengajar.

Dalam suatu proses pembelajaran, penilaian autentik mengukur, memonitor dan menilai semua aspek hasil belajar (yang tercakup dalam domain kognititf,afektif, dan psikomotor), baik yang tampak sebagai hasil akhir dari suatu proses pembelajaran, maupun berupa perubahan dan perkembangan aktivitas, dan perolehan belajar selama proses pembelajaran di dalam kelas maupun di luar kelas (Daryanto, 2014, hal. 123).

Sedangkan hasil wawancara peneliti lakukan di lapangan bahwa dari beberapa siswa kelas VIII SMP N 7 Muaro Jambi yaitu Dea siswi kelas VIII mengatakan bahwa "iya kalau awal pembelajaran Ibu guru menyampaikan penilaian apa saja yang akan dicapai tapi kadangkadang tidak setiap hari, ibu guru juga sering mengamati kami kalau lagi diskusi dan buat tugas". Siswi yang lain juga mengatakan yaitu Nabila Nuraini bahwa " biasanya Ibu guru memberi kertas penilaian diri itu satu semester sekali terus kalau soal dari Ibu guru terkadang essai, menghafal dan catatan". Siswi selanjutnya juga mengatakan yaitu Maya, bahwa “ iya Ibu guru pernah membagikan kertas untuk melakukan penilaian diri dan penilaian antar teman dan ibu guru selalu mencatat nilai kami saat di kelas". Berdasarkan hasil wawancara dapat diketahui bahwa pelaksanaan penilaian autentik di Sekolah Menengah Pertama Negeri 7 Muaro Jambi guru telah menggunakan penilaian autentik dalam pembelajaran di dalam kelas, guru juga telah menggunakan penilaian autentik di semua ranah penilaian, yaitu penilaian sikap, pengetahuan dan keterampilan. Pada hasil wawancara dengan siswa, siswa juga mengatakan bahwa guru bidang biologi telah melaksanakan penilaian autentik saat pembelajaran berlangsung, seperti guru menilai atau mencatat keaktifan siswa di kelas, siswa diminta untuk melakukan penilaian diri, menilai teman sejawat, membuat tugas proyek dan lain sebagainya.

Persiapan penilaian autentik sangat diperlukan dalam pembelajaran dan penilaian, seperti mengikuti seminar atau pun pelatihan yang diadakan oleh pihak sekolah untuk membantu para guru dalam melaksanakan penilaian autentik di kelas, pentingnya pelatihan ini agar semua guru dapat memahami dengan jelas cara penilaian ini dilakukan, karena kebanyakan dari Kendala penilaian autentik salah satunya adalah kurangnya dukungan dari pihak sekolah dalam melakukan pelatihanpelatihan yang seharusnya bisa dijadikan penunjang dalam pelaksanaan penilaian autentik di dalam pembelajaran. Persiapan selanjutnya yang harus di lakukan oleh guru yaitu membuat Rencana Pelaksanaan Pembelajaran (RPP) yang sesuai dengan silabus dan di dalamnya telah terdapat indikator dan skor penilaian. Pelaksanaan penilaian autentik yang dilakukan oleh guru biologi di dalam kelas yang sangat berperan saat pembelajaran berlangsung dalam pelaksanaan ini guru 
menggunakan media dan strategi dalam belajar, beberapa guru menggunakan cara berkelompok dalam mengajar dan kebanyakan guru mengambil nilai sikap dari keaktifan mereka saat berdiskusi, karena menurut para guru tidak semua siswa yang selalu mendengarkan teman mereka berbicara kedepan kelas, ketika itulah guru dapat menilai sikap mereka dan dari situ juga terlihat bahwa guru melibatkan siswa dalam pembelajaran, guru juga melibatkan siswa saat melakukan penilaian diri dan penilaian teman sejawat di dalam kelas, penilaian ini dilakukan satu semester sekali. Kemudian guru juga sering meminta mereka membuat media pembelajaran sebagai tugas kelompok maupun tugas individu sebagai pengambilan nilai proyek dalam pengambilan nilai keterampilan. Para siswa juga mengatakan bahwa guru sebelum mengajar terkadang menjelaskan penilaian-penilaian yang harus dicapai oleh siswa dan guru juga sering memberi soal lisan dan tulisan saat pembelajaran berlangsung, jika dari ulasan tersebut terlihat bahwa guru biologi telah melaksanakan penilaian autentik dalam pembelajaran berlangsung.

Berdasarkan lembar hasil kuesioner pada tabel 1 hingga tabel 11 dapat diketahui bahwa tanggapan siswa tehadap perencanaan penilaian autentik dikategorikan sering dengan arti lain baik berjumlah 39 siswa dengan peresentase $(100 \%)$, dan dengan respon guru dikategorikan selalu dengan arti lain sangat baik berjumlah 2 guru dengan persentase $(66,66 \%)$ kemudian pada tanggapan siswa terhadap pelaksanaan penilaian autentik dikategorikan cukup baik berjumlah 39 siswa dengan persentase (100\%) dan dengan respon guru dikategorikan sering dengan arti lain baik berjumlah 3 guru dengan persentase $(66,66 \%)$ dan pada tanggapan siswa terhadap teknik dan instrument penilaian sikap (afektif) dikategorikan kadang-kadang dengan arti lain kurang baik berjumlah 28 siswa dengan persentase (72\%) dan dengan respon guru dikategorikan jarang dengan arti lain cukup baik berjumlah 2 guru dengan persentase $(66,67 \%)$ sedangkan pada tanggapan siswa terhadap teknik dan instrument penilaian pengetahuan (kognitif) dikategorikan kadang-kadang dengan arti lain kurang baik berjumlah 39 siswa dengan persentase (100\%) dan dengan responden guru dikategorikan kadang-kadang dengan arti lain kurang baik berjumlah 2 guru dengan persentse (66,67\%) selanjutnya pada tanggapan siswa terhadap teknik dan instrumen penilaian keterampilan dikategorikan selalu dengan arti lain sangat baik berjumlah 38 siswa dengan persentase (97\%) dengan responden guru dikategorikan selalu dengan arti lain sangat baik berjumlah 3 dengan persentase (100\%), dan pada tanggapan guru terhadap analisis dan pelaporan (hasil) penilaian autentik dikategorikan jarang dengan arti lain cukup baik berjumlah 2 guru dengan persentase (66,67\%). Dapat disimpulkan bahwa tanggapan siswa perencanaan penilaian autentik baik, pelaksanaan cukup baik, penilaian sikap dan pengetahuan kurang baik dan penilaian keterampilan sangat baik sedangkankan tanggapan guru pada perencanaan dan penilaian keterampilan sangat baik, penilaian sikap dan analisis pelaporan (hasil) pelaporan cukup baik, pelaksanaan penilaian autentik baik dan penilaian pengetahuan kurang baik.

\section{KESIMPULAN}

Berdasarkan data dan pembahasan yang dilakukan, seluruh guru bidang studi IPA Terpadu materi Biologi sudah melaksanakan penilaian autentik. Guru sudah melaksanakan penilaian autentik pada saat proses pembelajaran yang meliputi tiga aspek penilaian yaitu sikap, pengetahuan, dan keterampilan. Namun, pada proses pelaksanaan penilaian autentik masih ada beberapa kendala yaitu banyaknya format penilaian yang harus dibuat oleh guru dengan ketersediaan waktu yang guru miliki terbatas sehingga membuat guru kurang maksimal dalam melaksanakan penilaian autentik. Banyaknya aspek yang harus dinilai dalam penilaian Kurikulum 2013, sehingga guru membutuhkan waktu yang lama untuk melakukan penilaian. 


\section{DAFTAR RUJUKAN}

Budiarti. S.R \& Sadikin. A. (2015). Pengaruh kartu kwartet animalia dengan model TGT terhadap pemahaman materi taksonomi hewan siswa SMAN 8 Kota Jambi. Jurnal BIODIK, 1 (1), 1-8

Cahyadi F \& Purwandari A. (2014). Penilaian Autentik Mata Pelajaran Matematika Kurikulum 2013 Guru Kelas IV Kota Semarang. Jurnal Mahasiswa Matematika. 4(2), 35-42.

Daryanto. (2014). Pendekatan pembelajaran saintifik kurikulum 2013. Yogyakarta: Gava Media.

Kunandar. (2014). Penilaian autentik (penilaian hasil belajar peserta didik berdasarkan kurukulum 2013). Jakarta : PT. Raja Grafindo Persada.

Muchtar. H. (2010). Penerapan penilaian autentik dalam upaya peningkatan mutu pendidikan. Jurnal Pendidikan Penabur. 9 (4).

Mutalazimah. (2008). Pengembangan model penilaian autentik untuk meningkatkan hasil belajar mahasiswa pada matakuliah statistika. Varia Pendidikan. 20 (2).

Pantiwati. (2013). Hakekat asesmen autentik dan penerapannya dalam pembelajaran biologi. JEMS (Jurnal Edukasi Matematika dan Sains).1 (1):1-10.

Rifka, Khaldun, \& Ismayani. (2016). Analisis pelaksanaan penilaian autentik kurikulum 2013 oleh guru kimia di SMA Negeri Banda Aceh Tahun pelajaran 2016/2017. Jurnal Ilmiah Mahasiswa Pendidikan Kimia. 2 (3), 248-225.

Sadikin, A., Aina. M \& Hakim. N. (2016). Penerapan asesmen berbasis portofolio dan jurnal belajar untuk meningkatkan kemampuan metakognitif dan motivasi belajar mahasiswa pada mata kuliah Perencanaan Pengajaran Biologi. Jurnal BIODIK, 2(2), 50-61.

Sadikin. A. (2015). Hubungan EQ (Emotional Quotient) dengan Hasil Belajar Mahasiswa Biologi Semester Ganjil Tahun Ajaran 2014/2015. Jurnal BIODIK, 1(1), 1-12.

Sadikin, A. (2018). Penerapan jurnal belajar untuk meningkatkan motivasi belajar mahasiswa pada mata kuliah Dasar - Dasar dan Proses Pembelajaran Biologi. Bioeducation Journal, 2(1), 70-75.

Sadikin, A. (2015). An Anlysis of Students Perception on the course of biology and biology education at Jambi University. Jambi: Proceding Seminar Internasional IAIN STS Jambi.

Sugiyono.(2013). Metode penelitian kombinasi (mixed methods). Bandung: Alfabeta.

Sugiyono. (2011). Metode penelitian kuantitatif kualitatif dan $R \& D$. Bandung : Alfabeta 